\title{
A flame of sacred love: Mission involvement of women in the 19th century
}

\author{
Author: \\ Johan Kommers ${ }^{1}$ \\ Affiliations: \\ ${ }^{1}$ Faculty of Theology, \\ North-West University, \\ Potchefstroom, South Africa \\ Correspondence to: \\ Johan Kommers \\ Email: \\ j.kommers777@gmail.com \\ Postal address: \\ Operadreef 94, 3845 GR \\ Harderwijk, the Netherlands \\ Dates: \\ Received: 10 Sept. 2012 \\ Accepted: 24 July 2013 \\ Published: 27 Sept. 2013 \\ How to cite this article: \\ Kommers, J., 2013, 'A flame \\ of sacred love: Mission \\ involvement of women in the \\ 19th century', In die Skriflig/ \\ In Luce Verbi 47(1), Art. \#652, \\ 12 pages. http://dx.doi. \\ org/10.4102/ids.v47i1.652
}

\section{Copyright:}

(C) 2013. The Authors.

Licensee: AOSIS

OpenJournals. This work

is licensed under the

Creative Commons

Attribution License.
Read online:

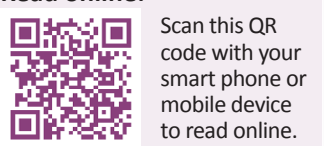

In the 19th century, women missionaries found acceptance in the public domain and opportunities for achievement that they were denied at home. Whilst they spearheaded movements for Christianising and modernising Asian (the focus of this article) and African societies through the evangelisation, education and physical care of women, many questions were raised about their motives and the way they executed their work. We need to rediscover the sacrificial dedication women had that made the 19th century the greatest century of Christian expansion. These were remarkable women who left everything behind - many of them leaving a permanent impression upon the people in whose cities they eventually resided - and who stand as examples to the present generation. Having lost most of the things the world prizes, they gained one thing they esteemed so highly. For them, the relative value of things temporal might go, provided that they could forever settle the eternal values. They lived out the words of Paul: 'I press on toward the goal for the prize of the upward call of God in Christ Jesus' (Phlp 3:14).

'n Vlam van heilige liefde: Sendingsbetrokkenheid van vroue in die negentiende eeu. Vroue-sendelinge het in die negentiende eeu geleenthede vir prestasie en aanvaarding in die publieke domein gevind wat hulle andersins misgun is. Hoewel hulle die voortou geneem het met bewegings vir die kerstening en modernisering van gemeenskappe in Asië en Afrika deur middel van die evangelisasie, opvoeding en fisiese versorging van vrouens, is hulle motiewe en die manier waarop hulle te werk gegaan het, bevraagteken. Dit is dus nodig om die opoffering en toewyding van hierdie vroue, wat die negentiende e eeu uitgesonder het as die belangrikste eeu vir Christelike uitbreiding, te herontdek. Hierdie merkwaardige vroue het alles opgeoffer en vele van hulle het 'n onuitwisbare indruk gemaak het op die mense in wie se stede hulle uiteindelik tuisgegaan het. Hulle staan uit as voorbeelde vir die huidige generasie. Al het hulle soveel dinge verloor wat deur die wêreld as belangrik geag is, het hulle veel gekry uit dit wat hulle persoonlik hoog geag het. Vir hulle het die relatiewe waarde van tydelike dinge min beteken, solank hulle die ewige waardes kon vestig. Hulle het voorwaar Paulus se woorde uitgeleef: 'Ek span my in om by die wenstreep te kom, sodat ek die hemelse prys kan behaal waartoe God my geroep het in Christus Jesus' (Fil 3:14).

The nineteenth century has been called 'Woman's Century' and the 'Century of Missions'; the dawn of one brought light to the other. (Butler 1904)

\section{Introduction: Women in the spotlight}

From 31 March until 24 June 2012, the museum Catharijneconvent had an exhibition titled 'Women in the spotlight: Nuns, martyrs, cleaners and clergywomen' (Kootte \& Schriemer 2012). ${ }^{1}$ The involvement of women in the rich church life in the Netherlands was shown. Pious women from early Christianity through to women working in the church today were very much in the public eye. According to the organisers of this exhibition, Christian belief 'feminized' in the 19th century. This can especially be seen in the missionary work of that century (Kootte \& Schriemer ibid:68-69). Women missionaries ran up against a lot of difficulties before being fully accepted as recognised missionaries. The involvement of women in missionary work calls for an assessment of this extraordinary missionary phenomenon of the 19th century.

Whilst the 20th century had a greater number of missionaries and converts, the 19th century saw a greater depth of impact. They - men and women - were people of one vision. Nowadays there is no question about women participating in missionary work. Their sisters, especially in the first decades of the 19th century, faced a lot of obstacles. Reflecting on the whole missionary 
movement from Europe, which was instigated by Britain, we see that it was difficult for women everywhere to be involved. Limited education had to be overcome, but this was compensated for by much evangelical zeal. The only way for women with a strong sense of evangelical duty to enter the overseas missionary field at that time was to marry a seminary graduate or an evangelist bound for foreign countries (Kent 2004:92).

After the Reform Acts of 1832 in Britain, progress was made all around in the economic, social and religious fields - much of it brought about by incredible individual ingenuity and innovation. The optimism and vitality amongst Christians kindled hope and faith amongst many young women for their share in these developments, especially in the evangelistic enterprise. In Victorian Britain, women campaigned a long time for equal educational opportunities so that they could break into the professions. Training colleges were established to produce teachers and governesses, women's university colleges started in London (Bedford College in 1849) and Cambridge (Girton in 1869 and Newnham in 1873). During the Crimean War (1854-1856), the conditions in the military hospitals in Turkey were terrible and the government desperately needed nurses. Florence Nightingale (1820-1910) and those whom she recruited, answered the War Office's request. In the home country, many women were conscious of the high stakes and knew that their work could advance the nursing profession and other professional charity work. Now they had the opportunity of doing jobs outside the kitchen and family - jobs from which the society had previously excluded them. The Crimean War was one of the causes that fundamentally shaped women's experiences. The image of nursing improved and it was believed that official work for women - in this case, nursing - should be seen as a respectable profession, which required professional teaching. In the United States, the experiences of female nurses on the battle fields of the Civil War made many people aware of the untapped resource of women's 'great executive ability and amount of energy' (cf. Chamberlain 1925). The shining example of a woman like Clara Barton, a nurse during the Civil War who founded the American Red Cross, made it possible for women to contemplate lives of professional service, which channelled their nurturing capacities outside the home and into the world at large.

British women wishing to be qualified as medical doctors were, in the first instance, not allowed to study medicine at one of the universities in Britain and met with bitter opposition. In America it was the same (Barret Montgomery 1910:188): 'To every orthodox mind a woman doctor was anathema'. In 1859, the Philadelphia Medical Society passed a resolution of excommunication against any doctor who lectured or taught in the Women's Medical College, and against every graduate of that institution. In 1849, Elizabeth Blackwell was admitted to study medicine in Geneva, after knocking at the doors of 12 medical colleges without success. Many followed and received their medical degrees from institutions in France, Switzerland or Germany. A bill to permit their registration in Britain was defeated. Legislation by Parliament finally passed in 1876 and restrictions on medical education for women were removed. Until far into the 20th century, Cambridge University remained an exclusively male environment. Women were not admitted as full members of the university, eligible to obtain degrees, until the late 1940s, and the Cambridge Inter-Collegiate Christian Union (CICCU) was all male until 1948.

Christian women students began a separate organisation in 1919. The amalgamation of the organisations was only realised in 1948 (for more on Christian student life in Cambridge, see Armitage 1993). The first pioneer women medical doctors were sent to India (Jayawardena 1995:7579). One of them, dr Fanny J. Butler, was sent to India in 1880 by the Church of England Zenana Missionary Society (CEZMS). The first qualified female doctor from the United States who went to India in 1869, was Clara Swain (18341910), an MD from Pennsylvania who belonged to the Methodist Women's Foreign Missionary Society. It was in America that women generated the greatest enthusiasm for missions for women, but their English sisters were the first to become independently involved in foreign missions. Also, the concept of 'faith' missions, which strongly advocated the involvement of single lady missionaries, came from British soil.

\section{Trailblazers}

Mission-minded women in the 19th century in America were admiring Ann Hasseltine Judson (1789-1826), one of the first women who left her country for a life overseas as a missionary wife. More or less an example of a Protestant icon, since a White women living in a 'heathen land' at that time was unheard of. She married Adoniram Judson and two weeks after their wedding they sailed from America to Calcutta (India), and from there were relocated to Burma. The couple met with a lot of problems. After having worked in Burma for nearly 14 years, Ann died in her thirties. During their time in Burma, she succeeded in learning Thai (Siamese) and translated Matthew's Gospel into that language. She was a remarkable woman who was valued for her sacrificial dedication to mission work.

In England, Mary Bethia Groves (1798-1831) spoke to the imagination of many. Having waited to get consent from her father, she married ('to her happiness') her great love, the dentist Norris Groves. Whilst her husband attended to the teeth, Mary walked to the poorer parts of Exeter to visit homes where people lived in great need. She also visited the prisons. Whilst in the prison chapel, the pastor preached on 'God has chosen the weak of the world' (1 Cor 1:27). This marked her conversion and she became 'active, decided, and with a strong independent judgment' (Dann 2004:24). The young couple with their little children heard the call of the Lord and decided to 'be ready to go anywhere' (Dann 2004:27). Having given away the dental practice and properties, they went on an adventurous journey via Russia to Persia, where they settled in Baghdad. Mary, again pregnant, started to learn Armenian, and began to work amongst the women 
and teach children in a school she had started. After many difficult years, Mary fell ill and died in 1831. At that time, the plague ravished thousands of the Baghdad inhabitants. Mary died young, as did many of her missionary sisters in that century. It was only in 1861 that Louis Pasteur discovered that infectious diseases were caused by bacteria, viruses, protozoa, et cetera.

Ann Judson in Burma and Mary Groves in Baghdad were for many women in England and America, who read about their work in mission magazines, an example to open up possibilities that were not common for women at that time. They opened new paths for women; that they could even take on professional roles. At that time, it was considered that women should not transgress gender boundaries, but both Ann and Mary revealed their conviction that the woman's sphere of work could be broader than the private space at home. Next to the duties at home, they had an independent ministry of their own. We see a gradual shift in thinking about women's involvement in missions. The Centenary Conference on Protestant Missions, held in London in 1888, clearly demonstrates this. ${ }^{2}$ The ideology of domesticity in the Victorian era slowly faded with the new focus on women, especially unmarried women, who undertook most valuable assignments in missions and who secured their own indispensable place in the whole of this work. They now looked at many problems from a global point of view. ${ }^{3}$

\section{'O bring us some female men'}

Western women were involved in missionary endeavour since the 18th century. However, their independent agency in the mission field did not really begin until the 1860s. The first women's missionary society in the world was organised in 1800 by Mary Webb. The formation of the 'Boston Female Society for Missionary Purposes' was more or less a revolutionary step for a woman to assume leadership of a religious organisation. Mary Webb was 'blazing a path, perilous for a young woman, through an unbroken wilderness' (Vail 1914:II). This organisation, and several others later on, were spin-offs from parent groups that provided day care and clothing for young children of working mothers, and supported the ministry of missionaries. In those days, women had their place and work at home, but outside activities in society and church were severely restricted. Mary, through her activism, contributed significantly to a changing mind that would, slowly, open the doors for women to enter into missionary service (Vail ibid:65-68, 107).

Miss Sarah Kilham was working in St. Petersburg when the mission party of Norris Groves, on their way to Baghdad, passed there. She was one of the first unmarried women to serve as an overseas missionary (Dann 2004:130-134).

2.'We must not allow [...] the ability and efficiency of so many of our female helpers, nor even the exceptional faculty for leadership and organisation which some of nor even the exceptional faculty for leadership and organisation which some of of man in Missions [...] Their work had become crucial in education, evangelism, medical missions, and benevolent ministries' (Scott et al. 2004:28).

3.For Ann Hasseltine Judson, see R.A. Tucker (1988:24-27) and C. Anderson (1972). For Mary Groves, see R.B. Dann (2004:18-20, 27, 47-48, 57-58, 130-134, 146, 166-173).
The primary way for women in the 18th century to go overseas, was to marry and go with their husbands bound for missionary work and serve in the evangelistic effort with their husbands. But they were seen merely as the wives of missionaries (Dann ibid:293): 'Merely a wife - going to the mission field because she was constrained to follow her husband.' They were not missionaries in their own right. ${ }^{4}$ Those who were single when going, only went with their parents or brothers. ${ }^{5}$ Neill (1982:256) says it in a short, but to the point manner: 'Most of these women were missionaries' wives rather than missionary wives.'

The early Methodist missionary endeavour of the Wesleyan brothers had a great impact on the British society. Women especially reacted positively to the message they heard, according to the Wesleyan ideal of the godly and harmonious household and the provision it offered to the individual believer. The new movement relied on the initiative, zeal and generosity of its adherents, both male and female. Within this movement, women took the lead in many new congregations and were allowed greater influence than by any of the mainstream Christian denominations. Methodism has been described as a 'woman's faith' and it equipped 'women with a realistic recipe for survival in an imperfect world' (Hufton 1995).

Many married women, having experienced the saving grace of the Lord Jesus Christ, sought to persuade their children, their husbands and other family members to follow their example, and in doing so acted as the spearhead of further Methodist advance. Many single missionary ladies in later decades mentioned the piety and prayers of their mothers as one of the reasons for them going to the mission field. ${ }^{6}$ The wisdom of these 'mothers in Israel' drew many young ones around them to spiritual counsel. It was Wesley himself who sanctioned the departure from an established pattern and gave women the freedom to preach the gospel. In this way, the Revival periods enlarged the horizons of ministry for women. Wesley once said to one of these ladies (McGregor 1832:38): 'Conscience will not permit you to be silent when God commands you to speak'. ${ }^{7}$ Women's influence appears to have been the most effective amongst members of their own sex. Within Methodism, the gender segregation of band meetings facilitated close links between the 'sisterhood' of believers, and many women emphasised the importance of such groups, both in the recruitment of new members and in mutual support and fellowship. ${ }^{8}$

4.Think of those who followed their husbands: Dorothy Carey (India), Mary Grove (Baghdad), Mary Morrison (China), Mary Livingstone (Central Africa), Priscilla Studd (Baghdad), Mary Morrison (China), Mary Livingstone (Central Africa),
(China, India, Africa), Ann Judson (Burma) and Maria Dyer (Malacca).

5.See Lydia Groves (sister of A.N. Groves), May Ann Aldersey (Malacca, China), Maria Newell (Malacca - she went with Samuel and Maria Dyer an married Karl Gutzlaf in 1829), as well as Burella and Maria Dyer (China - daughters of Samuel and Maria Dyer). Maria Dyer was married in 1858 to Hudson Taylor, the founder of the CIM.

6.Cf. the influence of mothers on Amy Carmichael, Margaret King and others. The same can be said of many men like Andrew Murray, who refer to the prayers of their mothers as the cause of going to the mission field. For those mothers, these words truly apply: 'The hand that rocks the cradle, rules the world.

7.Alice Cambridge was born in 1762 in Bandon, County Cork, Ireland, and joined the Methodist Society in about 1807 . She spoke at meetings all over Ireland, becoming one of the most famous Methodist female preachers. She died in 1829.

8.The young Alice Cambridge was introduced to Methodism by some women friends who were already members of the Methodist Society (McGregor 1832:15-17). 
Although implicitly denied by the great majority of Methodists, we see that many young women of those times chose another way to the conventional female destiny of marriage, motherhood and domesticity. Their religious commitments did not always coincide with the expectations of being tied in marriage and family affairs, or they had difficulty finding an awakened partner 'whose mind did not bend heavenward' (Abelove 1978:120). ${ }^{9}$ The opportunities Methodism offered to its female adherents were less radical than they appeared. Women who used their independence of belief and action, did so in the spirit of service rather than of rebellion against their position in society. 'Women's rights were simply not an issue that gripped them' (Tucker 1988:40). Women, married or single, going out in the mission field, worked side by side with their husbands or were loyal to the leadership of their sending organisation. There, where they were working alone on the mission field, we often see remarkable, strong women, keeping the vision..$^{10}$ Single ladies could give themselves wholly to the work. Their married sisters often met great difficulties on the mission field. Next to the work at home, assisting a husband and children, many shared the experiences common to many women of that generation. Childbirth, in particular, was a perilous undertaking for women before the use of sterile instruments and antibiotics. Many men - in the relatively safe Europe, but also in the mission - lost their young wives shortly after marriage ${ }^{11}$ Every pregnancy brought with it the prospect of death. In the 19th century, prolonged sickness and sudden death were a normal part of human existence. Life was never to be taken for granted. For many women in the early 19th century, a missionary call was a call to early death. 'Fancy, three ladies who sailed with K., and that is since I came (in 1885), are dead.' This is one of the entries in a letter Walker of Tinnevelli (South India) wrote in 1887 (Wilson-Carmichael 1916:149). Sanitation and a lack of understanding regarding how women were uniquely impacted by associated issues meant it was not unusual for a male missionary to have a line of three or four wives buried in the field; some had as many as six! They loved Christ enough to look these facts in the face and give everything for his honour and the salvation of the lost. Single ladies in the mission field did not meet the dangers connected with pregnancy and childbirth, but history shows that many single ladies married sooner or later whilst working in the mission. ${ }^{12}$

The new Charter in India removed the opposition to missionary work in 1813, and by 1830 there were nine societies active in that country. The Baptists of Calcutta started the first work amongst women in 1819 under the title 'Calcutta Female Juvenile Society'. By that time the appalling fact was that out of 40 million Hindu women, less than 400

9.For Wesley's views on marriage and celibacy, see Abelove (1978).

10.See Margaret King (China), Amy Carmichael (India), Mary Schlessor (Calabar, West Africa), Mildred Cable (China), Francesca and Eveline French (China), and Lilias Trotter (Algeria).

11.Like the missionaries John Panell (Latakia), Karl Pfander (Shushi/Baghdad), Henry Groves (Chittoor, India) and Hudson Taylor (China).

12.For example, Thomas Walker (CMS, India) married Miss Hodge (CEZM) in 1890. See Wilson-Carmichael (1916:115). could read or write. The call was for a lady to teach and train local women to be teachers. In 1821 Miss Mary Ann Cooke was selected for this work and, arriving in Calcutta, she was the first single female missionary sent to India (Denny 1901:2). The Indian women admired her: 'What a pearl of a women is this' (Denny ibid:2). To extend the benefits of Christian education to other parts of India, a society was formed - subsequently called the 'Indian Female Normal School and Instruction Society'. More or less operating interdenominationally, but initiated by the Church Missionary Society (CMS), this worked until 1880 when some members preferred the Society should work entirely with the CMS. They withdrew from the Society and formed the Church of England Zenana Missionary Society (CEZMS). In 1888, the name was changed to the Zenana, Bible and Medical Mission $(\mathrm{ZBMM}){ }^{13}$

One of the first institutions that articulated an awareness of the importance of recruiting unmarried women as missionaries was the London-based 'Society for the Promotion of Female Education in the East' (SPFEE, informally simplified to FES - Female Education Society [1850]), which was founded in 1834. Surprisingly, it was often men who saw the need for single women to enter foreign missions. David Abeel, an American clergyman, recently returned from China and was on his way to America, addressed a group of ladies in a private drawing room in London, pleading with them to form a society to support women who were called to teach overseas. ${ }^{14}$ He himself had worked in Macao and South-East Asia. There he had seen that many 'supportive' wives worked alongside their husbands in evangelising and teaching women, to which the men had no access. At that time, most missionary societies were strongly opposed to sending single women out alone. In the first years of Queen Victoria's reign, most British women lived under the protection of their families until they married. To live unmarried overseas was unthinkable. By that time the London Missionary Society (LMS) had sent just two single ladies and had resolved to send no more. The CMS only sent out 11 single women between 1820 and 1831, always to join relatives or friends. ${ }^{15}$ Abeel appealed to the ladies to take action - and they did! Abeel made the same request in Boston (Massachusetts), and the ladies there were as enthusiastic as their sisters in England. But his appeal was strongly opposed by a senior missionary leader, Rufus Anderson, and they reluctantly complied. Abeel's plea stirred the women hearers when he quoted a Chinese woman who had urged him before he left Asia: 'O bring us some female men' (Tucker \& Liefeld 1987:301). One of the ladies present at that time, Sarah Doremus, continued labouring for the cause of missions, and finally, in 1860, organised the Women's Union Missionary Society. (Tucker \& Liefeld ibid:300-302; Barret Montgomery

13.In 1901, 103 European missionaries, 51 assistants, 197 local teachers and $92 \mathrm{Bible}$ women were connected with the ZBMM. They worked in 68 schools, with 3739 students. More than 3000 zenanas [closed women quarters] and 1035 villages students. More than 3000 zenanas [closed women quarters]
were visited by the Bible women. See J.K.H. Denny (1901:9-10)

14.'The most important afternoon tea in history' (Barrett Montgomery 1910:21-25). About Abeel in England and America and his pleas for female missionaries, see Barrett Montgomery (ibid).

15.Within two years only two were left. The others had married or died (Murray 1992). 
1910:161-162). In 1843, Mary Ann Aldersey ${ }^{16}$ was the first single Western woman to set foot in China. The founding of the SPFEE anticipated a major period of growth in women's missions in the 19th century.

\section{Zenana - Women going to women}

Robert Morrison was one of the first Protestant missionaries to open the road to the 'Great Closed Land', as China was called. Since 1818, he had urged the formation of a society to send women abroad as missionaries, and even taught a class for them at his home in the quiet village of Hackney, just outside London. With reference to the need for unmarried women workers, he commented in Canton in 1822 (Broomhall 1924):

The missionary community should consist of persons of both sexes, possessing different qualifications and places and duties in it. To assist the pagan females to understand the doctrines of the Gospel, Christian females are essential; but missionaries' wives who are mothers, as soon they arrive in heathen lands, are seldom in sufficient health, nor have sufficient leisure to qualify themselves. Pious young women to acquire the pagan language and teach girls and grown women would be very useful. (p. 156)

Karl Gutzlaff (1803-1851), a significant missionary of the Netherlands Missionary Society (later independent) to China, also was one of the first to highlight the need for female involvement in ministry overseas. He clearly saw that only female missionaries had access to the women of China. The Chinese women had a significant influence over their husbands and Gutzlaff saw this as critical for the success of the gospel. In 1850 he called for 'pious females', those willing to adopt Chinese dress and who could evangelise within the Chinese context (Gutzlaff 1850:39). In this, Gutzlaff supported Morrison when he stated (Broomhall 1989):

It is sufficiently evident that without the aid of pious females no permanent impression can ever be made upon families, and that Christianity therefore will have no hold amongst the nation; hence the necessity of female laborers of the same stamp as the [...] male agents. (p. 332)

Openings for the involvement of women had come through the work of medical missionaries. However, male doctors were often prevented to visit sick women and because this medical missionary work needed consolidating, they emphasised that female doctors should work with them, since they saw that especially women had access to sick females. Gutzlaff's influence on Hudson Taylor, who applied his and Morrison's ideas through the Chinese Evangelization Society, was profound (Broomhall 1989:180). It was the deepest degradation and suffering of womanhood as well as the sexual abuse of little girls and boys, often based upon religious sanctions, that opened the eyes of missionaries and mission societies to use women to reach out to women who could otherwise not be reached. The connection of religion with immorality is one of the worst wrongs against womanhood in India. From babyhood, the growing boy

16.She was one of the students who followed the Chinese lessons of Robert Morrison In 1837 she sailed for Djakarta (Batavia), because at that time foreigners were forbidden to reside in China, and worked amongst the Chinese there and later on in Surabaya (1841). When Hong Kong was leased to the British, she decided to move to Macao, the Portuguese settlement on the Chinese coast. For more on her move to Macao, the Portugues
life, see Griffiths (2004:19-43). and girl are plunged into impure ideas on sex. Even the indigenous people are 'ashamed of the licentiousness of their great religious festivals' (Barrett Montgomery 1910:66) and the first women sent out found that they were to meet the most difficult problem in the whole field, 'the winning of heathen women and girls for Christ' (Barrett Montgomery ibid:86). ${ }^{17}$

The Church of England Zenana Missionary Society (CEZMS) was mentioned earlier. The name of this kind of mission had to do with the culture in India and China. For missionaries in these countries it was very difficult to come into contact with young girls and elderly women. In India parents welcomed daughters, loved and nurtured them, others were seen as a financial burden because they had to be clothed and fed until they married. Educating girls was considered a waste of money, so most girls grew up untaught and illiterate. In Asia, they were confined to their homes from around the age of 11 until they married at 14 to 18 years of age, after which they rarely left the house, except on special occasions. Especially amongst wealthy Hindu families, women's seclusion provided a barrier to the visitation of foreigners and outsiders. In Africa, girls had more freedom to move around, but they were just used to assist in household work or to care for a younger sister or brother until marriage. Especially in Asia, girls and women can only be reached by other women visiting their homes. Women going to women - that was the aim of the CEZMS. ${ }^{18}$ Bringing the Gospel of Jesus Christ to the women and girls of India, China, Ceylon and Singapore had to be done by women because the secluded lives of the majority of Asian women made them inaccessible to men.

In India, the zenana is the inner room of a house, and most women and girls from 12 years onwards were confined to these almost dark, secluded quarters, or zenanas for the most part of their lives. ${ }^{19}$ They were strictly separated from men, and for men who went out as missionaries it was almost impossible to meet the women and girls. ${ }^{20}$ The provision of education for girls was an almost unprecedented innovation. In 1821, William Ward, who was Carey's associate, wrote: 'To the Hindu female all education is denied [...] not a single school for girls, therefore, all over the country' (Smith 1885:73). Eighty years later, Amy Carmichael, whilst doing itinerant evangelising work in South India, wrote (WilsonCarmichael 1901):

Of course, wherever we possibly can, we try to get into the houses, and talk to the women alone. This is far the best way to get at them; here, as elsewhere, it is soul to soul dealing which tells [...] We always get groups of women, and any number of children, but never any young girls. They are shut up inside. (p. 20)

17.For the status of women in Eastern countries in the 19th century, see Barrett Montgomery (1910:45-69).

18.For the origin and the work of the CEZMS, see Wilson-Carmichael (1901:63).

19.The word zenana is derived from the Persian word zen, meaning women. In North India, the inmates are called purduhnashin, or curtain women, i.e. sitters behind the curtain. The word zenana refers to the women's (secluded) apartments (Warner Ellis 1884:51-52).

20.There was just a short time available for education, 'for when a girl marries she can no longer leave home to go to school, and any teaching she gets must be given during the necessarily short and occasional visits of the Zenana missionary. The life of a high-caste Hindu woman is at best, a dreary one. Shut up in small dark rooms, whose only outlook is an enclosed court, only occasionally - very occasionally whose only outlook is an enclosed court, only occasionally - very occasionally -
allowed to go out in a closed vehicle, she has no variety, and little pleasure. [...] One day like another, dreary, dull, monotonous' (Denny 1901:51). 
For mission agencies at that time, the men were the 'missionaries' and the wives' role was to support their husbands and mother their children. ${ }^{21}$ In 1824, Robert Morrison of the LMS was on leave in Britain when he made an appeal for more men and women to go to the East. He suggested the founding of a society to help single women to go out and start schools - but at that time there was only a glimmer of response. Morrison called for 'pious females' to 'become Chinese' to bring the Gospel to China's women, with whom even Chinese men could have few dealings. He believed that all Christians, of whatever sex or occupation, would 'subordinate all their personal and domestic concerns to the cause of our Lord Jesus Christ' (Broomhall 1924:156). He so believed in his idea that he had a class in his sitting room in Hackney three times a week to teach Chinese to some young women. ${ }^{22}$

During the mid-19th century, the movement for home education in the zenanas developed fairly rapidly. By 1872, more than 800 Indian women were being taught by the non-denominational Women's Missionary Union working in Calcutta and 1700 others by women of other missionary societies (Jayawardena 1995:28).

The CEZMS started in 1880 and began with 38 European missionaries, 23 assistants and 96 Indian workers. At the end of the third decade of the CEZMS' existence, the number of European missionaries was 211, assisted by 488 Indian fellow workers. There were 12030 zenanas opened for teaching, preaching and medical help, 5980 girls entered the 229 schools and 1970 villages were visited in 1911 (A.D. 1911:67, 244). One of the well-known CEZMS missionaries was Amy Wilson Carmichael who went in 1896 to the Tinnevelly district (South India) as a Keswick missionary and started the Dohnavur Fellowship there from 1901 onwards. Up until her death in 1951 and the years following it, hundreds of little girls and boys were rescued from a life of shame and prostitution. In 1900 in Palamcottah, Miss Swainson began to gather in her little family of the deaf and dumb from all parts of India. In 1899, the 'Home for Homeless Women' opened its doors in Calcutta to give wandering weary women and widows a sheltered life. ${ }^{23}$

\section{China Inland Mission}

It was the China Inland Mission (CIM) who welcomed a wide spectrum of men and women who worked in the mission. From the beginning of the CIM in 1865, single women were sent out to work closely with missionary wives to reach the women. As the founder of the CIM, Hudson Taylor and his

21.A practice performed by many Dutch denominational church mission societies until far into the second part of the 20th century.

22.'This act of considerable faith [...] was to have far-reaching consequences. Three of those women would travel "east of India", whilst China was still closed' (Griffiths 2004:13). For Indian parents to send their daughters to school was a big step. In 2004:13). For Indian parents to send their daughters to school was a big step. In a (etter, Mary Ann Wilson admitted that 'no one has had the courage to send the first 2010:49-50).

23.At the time of the census of 1891, there were 22657429 widows in India, 13878 children under four years of age, 238572 between four and fourteen. Life for the children under four years of age, 238572 between four and fourteen. Life for the
widows that time was so terrible that ' $t$ t $]$ he Brahmin woman's daily prayer is that widows that time was so terrible that ' $[t]$ he Brahmin won
she may die before her husband' (Denny 1901:57, 60). wife Maria Dyer ${ }^{24}$ led the way in mobilising men and women to work together in evangelism and church planting. Maria died at the age of 33 , but through her example had laid the foundations for the involvement of women in China and especially within the CIM.

The Taylors drew on the example of the zenana work in India, noting the need for modification of that type of work in the Chinese context. Taylor was inclined to see the deployment of women as the 'most powerful agency for carrying the gospel into China's homes' (Broomhall 1988:233). When the first CIM missionaries sailed on 25 May 1866 from the East India docks in London for their journey in the Lammermuir to Shanghai, the list showed eight single ladies in their twenties (Broomhall 1984:155). The work of the ladies in China was so successful that Taylor saw them as a powerful mission agency (Broomhall 1984):

In every direction our sisters have free access to the women in their own homes. [...] In its actual influence on the people at large, I am strongly inclined to consider it the most powerful agency we have at our disposal, and I would draw particular attention to it, being convinced that its value can scarcely be overrated. (p. 351)

Taylor's CIM was not denominationally restrictive and single ladies from various denominational backgrounds joined the new mission society, which offered them lots of opportunities to obey the call for missionary work. Some of the women were to become experts (Broomhall 1984:403). In 1879, Taylor sighed gratefully: 'The Lord increase the number of lady workers in China tenfold' (Broomhall 1988:234).

Taylor used women to act as secretaries representing him officially when he was not in the country - not only in China, but also in England. On 24 May 1870 he wrote to Emily Blatchley that, when she returned from China with Taylor's children, she had to represent him, even though she was at that time only 25 years old. Taylor's confidence in her was complete, so he wrote (Broomhall 1988):

May he make you so conscious of His indwelling [...] all-sufficient, and that in Christ Jesus there is no male nor female, that so far as moved by Him, and acting for Him, you are no longer a girl whose place is to keep back, retired and silent, but His instrument, called to adorn Him who is your adornment. (p. 233)

Broomhall sums up Taylor's use of women: 'It was largely left to Hudson Taylor to defy public opinion and bring about the change in the latter half of the century.' The criticism against the use of single ladies in missionary work was still strong. In 1863, the CMS was still opposed to that idea (Stock 1899):

October 1863 they passed the following resolution: That as there are already two Societies in whose principles this Committee have full confidence, whose professed object it is to send out ladies for schools and zenanas in India, this Committee is not prepared to take up that branch of missionary operations, except under very special circumstances. (p. 227) ${ }^{25}$

24.About Hudson and Maria, see Polluck (2004:116): 'Without Maria, Taylor never could have embarked on his life's work.'

25.Neill's (1982:217) conclusion is dated a little too early when he states: 'It was only in the middle of the nineteenth century that all the missions, Protestant and Roman Catholic, alike, began to send out single women. 
In Britain, the 'Ladies Association for the Promotion of Female Education amongst the Heathen' was formed in 1866 with its own funding, staff and magazine. The objectives were to recruit women as teachers who could help in the education of girls and support girls' schools. In the United States, Methodist women started the 'Women's Foreign Missionary Society' in Boston in 1869 with branches in other states.

\section{'The full flowering of women's missions ${ }^{26}$}

To understand the rise of women's involvement in missions from the second half of the 19th century, we must not forget that mission agencies were reaping the aftermath of the great Revival of 1859. That spiritual awakening had not only swept thousands of men and women into the Church of Christ, but for many, especially women, it had also prepared the way for new opportunities - a prospering of individual faith and effort. Lay people were involved in teaching and preaching and a passion for souls not yet saved, emerged. Young girls and women almost never raised their voices in the church, but now there was a real need for them to be involved in active church work. The consecrated energies of young converts were soon to be seen in the involvement in missions. Into this prepared soil, the seed thoughts of several newly formed mission agencies were providentially cast. Many young men and women, educated and uneducated, were kindled to fresh devotion. ${ }^{27}$ A class of workers, hitherto excluded from the spiritual ministries of the Church, came forward. There is a striking example of this in a letter from Mary Slessor ${ }^{28}$ in which she indicates the qualifications of new women missionaries (Livingstone 1923):

Consecrated, affectionate women who are not afraid of work or of filth of any kind, moral or material. Women who can nurse a baby or teach a child to wash and comb as well as to read and write, women who can tactfully smooth over a roughness and for Christ's sake bear a snub, and take any place which may be open. Women who can take everything to Jesus and there get strength to smile and persevere and pull on under any circumstances [...] if they have only a loving heart, willing hands, and common sense. Surely such women are not out of our reach. There are thousands of them in our churches, and our home churches have no monopoly of privilege in choosing to keep them. Spare us a few. Induce them to come forward. [...] and so gently lead them out of their timidity and accustom them to society that they may meet out in the world, and hand them to us. [...] They will not need fine English, for there is none to admire it. No one knows other than native languages, and I would gladly hail any warm hearted woman from any sphere if she would come to me. (p. 135)

We notice here the strong plea that Mary Slessor makes to the churches in England not to keep everything for themselves they have no 'monopoly' - but rather seeing the need to give some of their women for the mission. The Revival gave a great

26.This expression is in E.F. Kent (2004:92).

27. Hudson Taylor, on deputation work in Dublin and Belfast, told families to devote all their children for mission work. See Taylor \& Taylor (1946:58ff.).

28.Mary Mitchell Slessor (1848-1915), missionary, sent by the Scottish Missionary Society in 1878 to Calabar, West Africa. boost, but before that time things were gradually changing. Within the church, male domination was a predominant factor - the female contribution was primarily one of service and inspiration within the family and community.

New opportunities provided an innovative and daring time for single girls in Victorian Britain, willing to go out into missionary work. At that time it was impossible for them to pursue their ambition in England, and it was quite uncommon in India or elsewhere for single ladies to go out. In the first decades of the 19th century single female missionaries were not commonly accepted by the majority of mission agencies. This picture changed dramatically by the last quarter of that century. Between 1858 and 1887 most mission agencies established ladies auxiliary committees to recruit female missionaries. For young female adults, adolescence was marked by the formation of new emotional bonds by the necessity to make decisions about marriage and by the death of a parent or parents and the breakup of the family home. Religious commitment offered a means of distancing them from family obligations and social conventions and being free to be active and useful in church and mission service. By 1890, more than half of the Protestant missionary force in China were female. ${ }^{29}$ In India more than 700 foreign 'female agents' were in missionary service (Tucker \& Liefeld 1987:311).

\section{From helpmeets to fully recognised missionaries}

It was left to the faith missions to develop a new theological and practical approach. The opportunity to be fully involved in missionary work as well as the new areas opened up, made the CIM attractive to independent women. National leadership developed even more quickly under women. Here, the faith missions were reflecting the influence of the Keswick holiness teaching and the Wesleyan background within which many women had been prominent figures (Hayes \& Urquhart 2004:29-42, 30).

The Keswick teachings of sanctification and holiness grew into a major interdenominational event. Until today, the motto of Keswick is 'All one in Christ Jesus' - bringing together men and women from virtually all the different churches of English Protestant Christianity (cf. Pollock [1962] 2004:80). A full and complete surrender to Christ was preached at Keswick and this did not lead to a mystical quietness or loud emotionalism, but to a commitment to action. Consecration to God and the evangelisation of the world ought to go together. For a long time the Keswick week had a special missionary meeting. Being present at Keswick, many have heard God's call to go to the mission field. To Hudson Taylor, ${ }^{30}$ Keswick seemed a tremendous potential for the whole missionary cause, and he talked about Keswick as 'my happy hunting ground' (cf. Pollock [1962] 2004:80;

29.See Latourette (1929:407). According to Griffiths (2004:10), by 1900 there were two missionary women in China for every man.

30.In 1883 Taylorspoke for the first time at the Keswick Convention (see Sloan 1935:30-42). 
Rowlandson 1997:13). Since 1888, the missionary factor had a firm and sometimes dominating place in the yearly Keswick Conventions. The address of Pandita Ramabai ${ }^{31}$ made the Keswick week that year (1893) memorable. Sloan (1935:4950) began by saying that she had come 'to speak for the 140 000000 of Hindu women in India', and that she wanted '1000 Spirit-filled missionaries for India's women'. She asked for prayer that 100000 Christian women might be raised up in India to carry the Gospel to their needy sisters'. When a challenge was made at the meeting for those who were prepared to offer themselves for Missionary Service, 'about

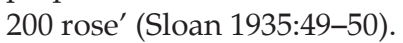

The revivals produced people with a spiritual experience that emphasised the power of God's Holy Spirit and the daily awareness of God's presence. This was exactly what Taylor sought in those who were to join the CIM and live by faith. This emphasis on spiritual rather than educational qualifications gave women equality with men. These very qualities, buttressed by the family devotions and a stable home life, contained the spiritual requirements necessary to survive in a hostile environment. Liberated from Victorian customs and expectation, they were also able to develop gifts in evangelism and teaching that would have been denied to them at home (Griffiths 2004:10). The 1851 census in Britain, published in 1862, showed the excess of single women and a widespread fear developed that Britain was overrun by 'redundant females' who could saw their chance to look for other job opportunities instead of the few they were supposed to do. People also argued that this was an opportunity for them to emigrate and to be engaged in philanthropic endeavours. Of those who stayed the longest on the mission field and had the most impact on the communities in which they worked, were the women who were dedicated to the institutions they helped to found, fund and manage (Kent 2004:93). Women's participation in missionary or other welfare work was stimulated through the example of ladies like Florence Nightingale.

Many middle class women were not content with the enforced idleness ${ }^{32}$ of their lives and saw in the lives of these 'cult figures' stepping stones for a nursing or teaching career, doing self-fulfilling work, which at the same time did not conflict with the contemporary ideals of female piety and self-sacrifice. Many of them sought work through religious institutions, as 'religious belief gave many women courage to move beyond conformity to social norms' (Smith 2010:54).

The major feminisation of missionary work did not come until the final decades of the early period of women's missionary work. In the first decades of that age, we saw that most women involved in missionary work were marginalised helpmeets of the missionary. Those who worked as single lady missionaries more or less pushed the social boundaries on women's positions in Victorian Britain.

31.Pandita Ramabai (1852-1922) was called the 'Mother of India'. She was a poet scholar and pioneer of the rights of women. She bridged the spiritual traditions of the East and West (see Dyer 1925 and Adhav 1979).

32.The census of 1860 reported, for the British Islands, that $30 \%$ of all women over 20 were unmarried.
Women missionaries intervened on the basis of love for their heathen sisters, to save them by teaching them the Gospel as well as better ways of living. Whilst on furlough in 1821, William Ward of the Baptist Missionary Society (BMS) in Serampore promoted the educational efforts in India and made a direct appeal to the ladies calling attention to the neglected state of females in India. Alexander Duff, also a promoter of English language education in India, supported the idea to educate women by women. The arguments used were not all free of the thinking that British culture was superior and more desirable for the Indian men and women. Women, once they had converted to Christianity and accepted British social morals, would be able, they thought, to spread their influence through entire families. The correspondence of Mary Ann Cooke made it clear that the relationship she cultivated with her students was one of superiority. She spoke about women living with their belief as 'artful, deceptive idolators', 'wicked people', 'grossly ignorant'. 'I am most thankful I have been brought among these poor creatures' (Smith 2010:16).

Using women as teachers required more standardisation of the necessary qualifications for the would-be candidates approved to teach in the field. It was not until the 1880s that they could attend certain colleges for that purpose. Mission committees frequently rejected a candidate, because 'her education did not seem to be sufficient' ('Missions to Women' in FES minutes 11/30/1835). Candidates had to go for some months to the Borough Road School, a teaching and training institute, to qualify as a teacher and also to learn what the education standard in Britain was. After 1854 the FES published a magazine called Female Missionary Intelligencer, which printed letters, stories and anecdotes from missionaries abroad. These publications portrayed women missionaries in a heroic light and called for other women to support them or even follow in their footsteps. These were women of exceptional courage, resolution and ability, facing toils and responsibilities they would not have when staying at home. They went, because they had heard the call.

\section{Channelling religious devotion}

The mission movement facilitated the spiritual gifts of men and women. After having been called, the denominational agencies ordained the men and their wives went with them. The CIM moved away from that concept, and accepted ladies and offered them big responsibilities. In a letter to her friend, as early as 1811, Ann Hasseltine Judson searched her heart for its motives. She loved her husband and followed him to Burma, but still she claimed that God had called her as a woman to serve him overseas (Griffiths 2004):

Nor were my determinations formed in consequence of an attachment to an earthly object; but with a sense of my obligations to God, and with a full conviction of its being a call in providence, and consequently my duty. (p. 318)

In the commissioning service, the Judson's pastor especially charged Ann to take the gospel to the women. Though it was not possible in their church at home at that time, things worked differently overseas. For the CIM, Taylor stated that 
'the sisters be recognized as equals' (Broomhall 1988:382) and he would like 'our sisters [...] to come out in ten times the number' (Broomhall ibid:387). By that time, in 1885, Taylor was, secretly, planning 'that more and more women were going inland, deep into pioneering situations. Keep it quiet until success or otherwise appears' (Broomhall ibid:387). ${ }^{33}$ For the emerging churches, women's involvement was often motivated by the fear that indigenous leadership was threatened by male missionaries who could not cope with their counterparts. The missionary women presented no threat to male indigenous authority and were faithful and loyal to the male indigenous leadership.

Many missionary authorities rejected the idea of women missionaries $^{34}$ and the social morals of the time gave missionary work for single women an aura of respectability, but the women were not discouraged to respond to the calls to work in foreign missions. ${ }^{35}$ Since all the application correspondence of the FES has been lost, it is hard to say what drew all the applicants to apply, but one attraction was 'the contemporary romantic reputation of missionaries' (Smith 2010:36). Within the law, women wanted to be fully recognised by the state. It is said (Barrett Montgomery 1910):

In all the English-speaking world the only woman whom the law recognised as a person was the unmarried woman. The married woman, in the eyes of the law, ceased to exist the moment her vows were said. (p. 5$)^{36}$

From 1848 onwards the married women's rights gradually changed in America. Women with mission aspirations stirred the feelings of many of their contemporaries.

The many 'psychobiographies' of heroic lives of missionary men and women, published in the 19th century, portrayed individual missionaries in a hagiographic light. The growing library of female biographies, mostly authored by the husbands of deceased missionary wives, was gaining a lot of response in Britain and Germany. ${ }^{37}$ The vision of a romantic, self-abnegating woman dedicated to a higher religious cause was gaining cultural capital in Europe in the 1830s and 1840s. ${ }^{38}$ With the institutional backing of the FES, single women regularly began to go out as missionaries. Especially from the 1850s onwards, the involvement of ladies in the missionary work grew steadily.

33.Broomhall (1988:387) here states that Taylor had in mind the staffing of a large region almost entirely by women.

34. In America women's involvement in missions was long debated and met a lot of opposition. Note the words of an influential church leader: 'What is to become of this Women movement in the Church? Let them alone - all through our history like movements have started. Do not oppose them, and it will die out' (Barrett Montgomery 1910:30)

35.See Smith (1910:35). 'The society [FES] started to receive a steady stream of application letters' (FES minutes 11/27/1835; 10/21/1836).

36.See Barrett Montgomery (1910:5): 'The remark attributed to a fond lover, "We shall be one, darling, and I will be that one", accurately and succinctly states the common-law doctrine of woman's rights.' Recently, Mr. Arthur Savage, Guildford (England) wrote to the author that this statement has never been true in England.

37.Cf. Dyer (1900). The nearly 40 pages of the Appendix (pp. 153-190) give many testimonies to her 'wholly consecrated and devoted life' (p. 154), 'she was a remarkable women [...] but more than all was her entire consecration and sweet personality' (p. 161), although she herself 'avoided the sensational' (p. 166).

38.Cf. Charlotte Bronte's Jane Eyre, published in 1847. Jane declines the prospects offered by St. John Rivers to follow him in his missionary calling. Jane, feeling her life in England is without future, was willing to go to the mission field, but refused to be St. John Rivers' wife. Was she looking forward to an idealised, romantic vision of a missionary who could be a woman as well as a man?
Not the excitement or the romantic feelings, but the zeal for the glory of God should prevail, and FES was searching the applications for ladies who wanted to obey the will of God. Mary Ann Wilson described what sort of agent the society should send to India: 'The lady should be a sensible, middleaged person, with a strong decision of character' (Smith 2010:37). She also emphasised the importance of physical stamina in order to resist the dangers of the climate as well as the ability to tolerate a largely unrewarding existence (Smith 2010:57-58): '[W] require active, cheerful good-tempered persons, who can be as happy alone, as in society [...] women agents should adhere to contemporary ideals of Christian humility, chastity, and respectability'. Mostly schoolteachers, governesses and clergymen's daughters qualified. There were few other jobs that a respectable woman could do in the early Victorian period.

Women missionary work changed after the 1880s. Work that began in weakness, stood in power several decades later. Whilst the number of single missionary women could be counted on one hand in the middle of the century, in 1909 there were 4710 unmarried women in the field. In 1861 there were very few organised women's societies, but in 1910 there were 44 in America alone and 500 agencies worldwide working in the field (Barrett Montgomery 1910:243-244, 249). Women's missionary work had become widespread, but the world in England and on the mission field had changed. English-educated Indian elites were becoming an active force in colonial society and politics. ${ }^{39}$ More girls were educated. In a pamphlet ${ }^{40}$ published by the FES it was stressed that it was still very difficult to reach the women - so the zenana work had to go on in full force. By that time the FES was sending women to China, Africa and the Middle East, but the work in India's zenanas took up a larger and larger part of the society's business.

The deepest motivation for women to go to the mission field was an act of faith. According to Griffiths, two out of four of those who went, laid down their lives within a couple of years (Griffiths 2004:323). The influence women had in the progress of the Gospel and the mutual relations between the mission and the indigenous Christians cannot be overestimated.

From 1800 until the end of the 19th century there was a dramatic change. When Mary Webb for the first time organised the women to be involved in missionary work, she could not have dreamed that a male missionary, after 60 years in the mission to India, commented 80 years later (Flemming 1986):

My honest opinion is that many of the Ladies I have known have been superior to many of all our male workers in [all] that goes to constituting the true missionary. Their intense earnestness, their love to the people, their zeal, their untiring energy, and their log-suffering patience have been far greater than in the men [and after having mentioned some of these women] I only wish we had hundreds more like those I have named. (pp. 11-12)

39.The Indian National Congress was founded in 1884.

40.The pamphlet was called 'Light through Eastern Lattices: A plea for Zenana captives by the society for promoting female education in the East on the occasion of its jubilee' - published in London in 1884 
Much of their work was a pragmatic response that took advantage of the new spiritually charged atmosphere engendered by the religious changes taking place in the 19th century. Their achievements in the 19th century are in a sense the most dramatic of all missionary achievements, because their choice was never made deliberately. We can refer to their phenomenal courage and their unique contribution. Going - often as single missionary women - to Asia, Africa or to one of the Pacific islands, they demonstrated that there was another career open to women besides marriage. They were even raised in the Victorian age, the age of marriage. In the missionary field, they introduced the teaching and nursing professions as channels through which young Asian (or African) women could serve their own people. They channelled religious devotion away from, often sectarian, England to a constructive mission to the world and discovered opportunities for their sisters of the next generations. The indelible mark women made on missions was noted in a mission periodical in 1910: 'In Christianising foreign lands, the woman physician is an absolute necessity. No other human being has the privileges in the harem, the zenana, or the humblest home' (Curtis in Tucker \& Liefeld 1987:497).

\section{Missionary women's perspectives in a time of globalisation}

It can be said without hesitation that women's involvement in 19th century missionary work has been a tremendous one - they even outnumbered the men. Shown the lives, the enthusiasm and devotion, combined with practical love and ability, ${ }^{41}$ the involvement of women in missionary work is still one of the most exciting areas of historical inquiry captivating as well as very touching. Their work in foreign missions has been without precedent. They were often viewed as 'God's second best', but their motivation and their sacrificial love for the people they were sent for, levelled the barriers. 'God sends us to the heathen for two purposes, to do them good, and to find a grave for a good self' (WilsonCarmichael 1895:119). Women's ministry was seen as service and mostly excluded from authoritarian responsibilities. During the 19th and 20th centuries, they were "present, but silent' (Robert 2002:12).

Today, the disqualification of women in leadership positions and church ministry is looked at from another perspective. In government as well as in church institutions, women now have a leading role. For the involvement of women in 21st century missionary work, the differences concern the interpretation of Scripture and its application to contemporary circumstances (cf. Tucker \& Liefeld 1987:440). Their work has become crucial in education, evangelism, medical missions and benevolent ministries.

In the light of God's global vision for women, mission organisations still need to reflect on their denominational and

41.A striking example of utter devotion and love is seen in the life and death of the missionary doctor, Eleanor Chestnut. When asked about the scars on her leg, she brushed the question aside, but later a nurse revealed that a skin graft for a 'goodfor nothing coolie' (Tucker \& Liefeld 1987:497) had come from the doctor's ow leg. Before she was martyred in1905, her final act of service was to rip a piece of material from her own dress to bandage an injured child (Speer 1909:108-109). theological differences to see if they are on track with God's intention for women being involved in missionary work. The gender division after World War I cannot continue today, because the polarised worlds of women are intersecting. 'The world has grown smaller because of advancing technology, inexpensive and open communication, social networking, and the forces of globalization' (James 2011:179). In this second decade of our millennium, God strategically opens wide windows of opportunities that call for Gospel action where women are the participants in a unique venture of Christian womanhood. Many Asian and also African women began to acquire professional status in the 20th century and did not experience some of the gender barriers Western women had to face. Not allowed equality in evangelistic work, it is shown that 'women were [...] central players in the spread of and indigenization of Christianity' (Prevost quoted in Seton 2013:206).

The contribution of Dana Robert, opening keynote speaker of the 2010 Edinburg Mission Conference, towards the woman's role in missionary work today is essential. Robert (2010) stated in an interview that most churches today consist of women and that Christianity will become a 'women's religion'. Formerly, and still nowadays, men were and are the gatekeepers with the responsibility for the structure of the church. Women are good for service, and had diaconal roles in which they excelled. They are able to create and maintain one-on-one relationships. So the demographic thought of gender in the actual mission situation cannot be overlooked. In the creation story, God made humanity his image bearers - male and female. The only time when God says: 'It is not good' is when the man is alone. But after God created Eve, we hear: 'It is very good'. Men and women are strategic to God's vision for the world.

To meet the demands of the post- $9 / 11$ context, it is agreed that a new style of service and leadership is needed, even to redefine spirituality. In today's missionary movement, the partnership between men and women, and the role of women in particular, is increasing. The growth and maturity of indigenous church leadership on the mission field led to a missiological emphasis on partnership, which suggested a diminished need for 'Western women in Eastern lands'. For the sake of organisational efficiency, most of the older women's missionary societies were forced to merge with denominational boards, who were dominated by men, after World War I. These and other developments called into question the need for gender-based separatism in missionary work. Dana Robert (2005:5) wrote that a growing influence in the realm of world missions continues through 'an impressive array of mission societies' .

Studies on women in global missions are primarily qualitative biographical studies, written by Western women about Western women, with a focus on women as influencers, social reformers, advocates and educators. Christianity is actually growing in the global South. "The current demographic shift in world Christianity should be analysed as a women's movement' (Robert 2002:6). We 
still lack trustful gender-based data. The following data is obtained from 'Global Table 2' in Missiometrics 2007 (Barrett, Johnson \& Crossing 2007). Here we read that in 2005 there were over 4.4 million women involved in full-time Christian work around the world, including home pastoral care, home mission and foreign missions. Forty-five percent of all these women constituted nearly half of all full-time foreign mission personnel. It is also concluded that women constitute about $56 \%$ of all background supporters in missions (Barrett et al. 2007). These facts show that more strategic training and especially the strategic deployment and utilisation of women are needed. They have administratively achieved equality with men in the mission field in the 20th century and now have key roles in the spread of the Gospel. In a recent study of Anglican women missionaries has shown that 'women were [...] central players in the spread of and indigenisation of Christianity' (Prevost 2010:4). A recent study (Seton 2013) shows that many Tamil Christian women are active in:

... spreading the Gospel and sustaining and extending the Tamil Church, while in China - reckoned to have one of the fastest growing Christian movements in the world - there were, in 2005, around 8000 women evangelists in registered churches alone. (p. 206)

By the mid-1990s, ' $[t]$ wo-third of the 88000 were sent by 1600 non-western agencies' (Robert 2005:15). Today the geographic spread of the Gospel by direct evangelism, radio, internet and other social media, i.e. web-related mission, causes people from almost every nation, tongue, and tribe worldwide to be able to hear the Gospel. The central, primary theological warrant for missionary work has always been the vision of the Kingdom of God (cf. Robert ibid:8-11).

Young women today are far more outspoken and independent than their counterparts in the 19th century had been. A majority of these women come from non-Western countries. In the West, Christians from affluent countries may be losing their ability to live with inconvenience, stress and hardship, as there is more and more emphasis on comfort and convenience. The whole situation of the church in the West has changed. This brings Ajith Fernando to the heartsearching question (Fernando 2001:25): 'Might the West soon disqualify itself from being a missionary-sending region? I think we are seeing some embarrassing examples.' Also, in the process of learning from others, the West has been very slow. It took a long time before the leading mission societies saw that the reluctance and the feeling of superiority of the West need to be checked and modified to understand the attitude of men and women of alien countries and creeds. Often women have been more sensitive in seeing the real needs of their sisters in other cultures. The contribution women in the 19th century gave to the mission through their (often) many years of service, challenges us to be in the race, focus on the Gospel and call people willing to die for it. The women who went as missionaries in the 19th century exercised an authority on missions that few men and women in our era can match.

\section{Conclusion}

The influence and the impact of the work of the 'Victorian lady missionary' characterised as 'resourceful, selfsacrificing, dedicated, and willfully' (Kent 2004:103) makes it clear that their influence has been felt for decades in the countries where they served and within the whole world of missions. Through their lives they have earned the right to be heard today. We continue seeing them with all the physical and spiritual triumphs and defeats, intensely feeling the cost of the cross of Christ Jesus. Working in God's Kingdom, to follow and live out the Great Commission, the 21st century 'Tabitha's' live and work as disciples (Ac 9:36-43) - just as their 19th century sisters, who are their shining examples. In the world church today, we assume that mission is a 'multidirectional enterprise in a global context' (Robert 2002:25). Women, in their holistic approach to missionary work, show us the undeniable story of courage, equality and partnership that reflects the Gospel and the world's desire to see that the flame is still burning.

\section{Acknowledgements Competing Interest}

The author declares that he has no financial or personal relationship(s) that may have inappropriately influenced him in writing this article.

\section{References}

A.D., 1911, Until the shadows flee away: The story of CEZMS work in India and Ceylon, Marshall Brothers, London.

Abelove, H., 1978, 'The sexual politics of early Wesleyan Methodism', in J. Obelkevich and J.F. Lyndal, Providence and patriotism in early America 1640-1820, pp. 119126, University Press, Charlottesville.

Adhav, S.M., 1979, Pandita Ramabai, Christian Literature Society, Madras.

Anderson, C., 1972, To the golden shore: The life of Adoniram Judson, Zondervan, Grand Rapids.

Armitage, C., 1993, Reaching for the goal. The life story of David Adeney, ordinary man, extraordinary mission, Harold Shaw Publishers, Wheaton.

Barrett Montgomery, H., 1910, Western women in Eastern lands, Macmillan, New York.

Barrett, D., Johnson, T. \& Crossing, P., 2007, 'Missiometrics 2007: Creating your own analysis of global data', International Bulletin of Missionary Research 31(1), 25-32.

Broomhall, A.J., 1984, Survivors' pact: Book four of Hudson Taylor and China's Open Century, Hodder \& Stoughton/OMF, London.

Broomhall, A.J., 1988, Assault on the Nin: Book six of Hudson Taylor and China's Open Century, Hodder \& Stoughton/OMF, London.

Broomhall, A.J., 1989, Barbarians at the gates: Book one of Hudson Taylor and China's Open Century, 2nd edn., Hodder \& Stoughton/OMF, London.

Broomhall, M., 1924, Robert Morrison. A master-builder, George H. Doran Company, New York.

Butler, F.A., 1904, History of the Women's Foreign Missionary Society, Kessinger Legacy Reprint, Nashville. PMid:17797921

Chamberlain, M., 1925, Fifty years in foreign fields: A history of five decades of the Women's Board of Foreign Missions Reformed Church in America, Women's Board of Foreign Missions, New York.

Dann, R.B., 2004, Father of the faith missions: The life and times of Anthony Norris Groves (1795-1853), Authentic Media, Waynesboro/Bucks.

Denny, J.K.H., 1901, Toward the sunrising: A history of work for the women of India done by women from England (1852-1901), Marshall Brothers, London.

Dyer, H.S., 1900, A life for God in India: Memorials of Mrs. Jennie Fuller of Akola and Bombay, Fleming H. Revell, New York/London.

Dyer, H.S., 1925, Pandita Ramabai. A great life in Indian missions, Pickering \& Inglis, London.

Fernando, A., 2001, An authentic servant. Spiritual ministry: Its paradoxes of death and life, joy and pain, 2nd edn., OMF, Singapore. 
Female Education Society (FES), 1850, Female education among the heathen, as recorded by Edward Sutter in the history and correspondence of the Society for Promoting Female Education in the East, London.

Flemming, L.A., 1986, 'Women and witness', in R.A. Tucker (ed.), Guardians of the Great Commission, p. 61, Zondervan, Grand Rapids.

Griffiths, V., 2004, Not less than everything: The courageous women who carried the Christian Gospel to China, Monarch Books/OMF, Oxford/Grand Rapids.

Gutzlaff, K., 1850, The Gleaner, Lawrence Academy, Groton, Massachusetts.

Hayes, A. \& Urquhart, D., 2004, Irish women's history, Irish Academic Press, Dublin.

Hufton, O., 1995, The prospect before her: A history of women in Western Europe (1500-1800), Harper Collins Publisher, London.

James, C.C., 2011, Half the church: Recapturing God's global vision for women, Zondervan, Grand Rapids.

Jayawardena, K., 1995, The white woman's other burden: Western women in South Asia during British colonial rule, Routledge, New York / London.

Kent, E.F., 2004, Converting women: Gender and Protestant Christianity in colonial South India, University Press, Oxford.

Kootte, T. \& Schriemer, I., 2012, Vrouwen voor het voetlicht: Zusters, Martelaressen, Poetsengelen \& Dominees, W. Books, Utrecht.

Latourette, K.S., 1929, A history of Christian missions in China, SPCK, London.

Livingstone, W.P., 1923, Mary Slessor of Calabar, Pioneer Missionary, 20th edn., Hodder \& Stoughton, London.

McGregor, J.J., 1832, Memoir of Miss Alice Cambridge: Compiled from her papers and the communications of friends, Martin Keene \& William Curry, Dublin.

Murray, J., 1992, 'Anglican and Protestant missionary societies in Great Britain: Their use of women missionaries from the late 18th to the late 19th century', Exchange 21, 1-28. http://dx.doi.org/10.1163/157254392X00101

Neill, S., 1982, A history of Christian missions, 9th edn., Penguin Books, Aylesbury.

Pollock, J., [1962] 2004, Hudson Taylor and Maria: A match made in Heaven, Christian Focus, Fearn, Tain, Ross-shire.

Prevost, E.E., 2010, Communion of women: Missions and gender in colonial Africa and in British Metropole, Oxford University Press, Oxford.

Robert, D.L. (ed.), 2002, Gospel bearers, gender barriers: Missionary women in the twentieth century, Orbis Books, Maryknoll, New York.
Robert, D.L., 2005, 'The great commission in an age of globalization', in W.S. Gunther \& E.A. Robinson (eds.), Considering the Great Commission, pp. 5-22, Abingdon Press, Nashville.

Robert, D.L., 2010, Dana Robert on Edinburgh 2010. Question 3 - Women, video on YouTube.com, Center for Global Christianity and Mission, Boston University School of Theology.

Rowlandson, M.L., 1997, Life at the Keswick Convention, OM Publishing, Carlisle.

Scott Moreau, A., Corwin, G.R. \& Mcgee, G.B., 2004, Introducing world missions: A Biblical, historical and practical survey, Baker Academic, Grand Rapids.

Seton, R., 2013, Western daughters in Eastern lands: British missionary women in Asia, Praeger, Santa Barbara/Oxford.

Sloan, W.B., 1935, These sixty years: The story of the Keswick Convention, Pickering \& Inglis, London.

Smith, G., 1885, The life of William Carey: Shoemaker and missionary, J.M. Dent \& E.P. Dutton, London, viewed 26 August 2013, from http://www.biblebelievers.com/ carey

Smith, J., 2010, 'Ladies and females: Women's missionary and educational work in nineteenth-century India', Senior Thesis Seminar, Department of History, Columbia University.

Speer, R., 1909, Servants of the King, Fleming H. Revell Company, New York.

Stock, E., 1899, The history of the Church Missionary Society, vol. II, CMS, London.

Taylor, H. \& Taylor, G., 1946, The growth of a work of God, 12th edn., Hodder \& Stoughton, London.

Tucker, R.A. \& Liefeld, W., 1987, Daughters of the Church: Women and ministry from New Testament times to the present, Zondervan, Grand Rapids.

Vail, A.L., 1914, Mary Webb and the Mother Society, American Baptist Publication Society, Philadelphia.

Warner Ellis, H., 1884, Our Eastern sisters and their missionary helpers, Anson D.F. Rudolf \& Co., London.

Wilson-Carmichael, A., 1895, From Sunrise land: Letters from Japan, Marshall Brothers, London.

Wilson-Carmichael, A., 1901, From the fight, CEZMS/ Marshall Brothers, London.

Wilson-Carmichael, A., 1916, Walker of Tinnevelly, Morgan \& Scott, London. 